
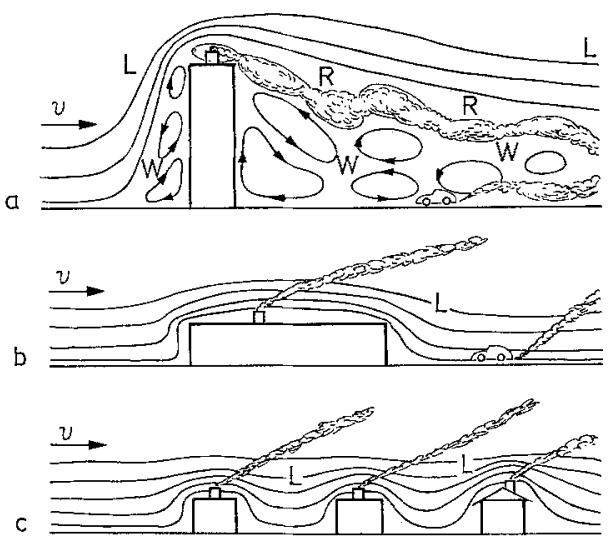

Fig. 1. a) Luftströmung an einem Hochhaus mit 8 Stockwerken bei Windstärke $3(v=5 \mathrm{~m} / \mathrm{s})$, also bei einer schwachen Brise. b) Luftströmung bei einem Flachbau mit 2 Geschossen bei schwacher Brise $(v=5 \mathrm{~m} / \mathrm{s})$ bis stürmischem Wind ( $v$ $=20 \mathrm{~m} / \mathrm{s}$ ). Erst bei $v>20 \mathrm{~m} / \mathrm{s}$ setzt Turbulenz ein. c) Luftströmung bei zweistöckigen Einfamilienhäusern bei schwacher Brise $(v=5 \mathrm{~m} / \mathrm{s})$ bis Sturm $(v=23 \mathrm{~m} / \mathrm{s})$. Erst bei $v>23 \mathrm{~m} / \mathrm{s}$ setzt Turbulenz ein

Wer Rauchringe blasen kann oder $\mathrm{PH}_{3-}$ Wirbelringe zu beobachten Gelegenheit hat, weiß, daß Wirbel lange Lebensdauer haben und über weite Strecken ziehen können und dabei ihre Substanz mitführen. Das gilt für größere Wirbel in höherem Maße. Zyklone ziehen um die halbe Erde und führen die in ihnen enthaltenen Luftmengen mit sich.

Hinter Hochhäusern liegt eine „Wirbelstraße" von vielen $\mathrm{km}$ Länge. Hier werden Staub, Kraftfahrzeugabgase und chemisch verdorbene Luft gleichsam als Wirbel "verpackt" und ziehen in Bodennähe entlang, bis sie abgekühlt sind und damit die Tendenz zum Aufsteigen in die hohe Atmosphäre verloren haben. Der Rand $R \ldots R$ der Wirbelstraße (Fig. 1a) ist fuir Gase unïberschreitbar; so bleibt die verschmutzte Luft der ganzen Stadt als Atemluft angeboten.

Teiche und offene Schwimmbäder verschmutzen in Städten mit Hochhäusern schnell. Die Bewohner fliehen eine solche Stadt auch dann, wenn sie selbst nicht in Hochhäusern wohnen. Die Hoffnung, die Stadtflüchtigen wieder zurückholen $\mathrm{zu}$ können, wenn man übliche Siedlungen zwischen den Hochhäusern schafft, ist gering. Die nur wenige km entfernten Hochhäuser entwerten auch dieses Zwischengelände; durch Hochhäuser spart man kein Gelände ein; man entwertet ein Vielfaches des vermeintlich eingesparten.

Eingegangen am 11. April 1978

\title{
New Diagram Lines in the L-Emission Spectrum of Neodymium-60
}

\author{
B.D. Shrivastava and Devendra Singh \\ School of Studies in Physics, Vikram University, Ujjain 456010, India
}

The L-emission spectrum of neodymium has been studied by several investigators [1], but there are still many transitions, the lines corresponding to which have not yet been observed. It was therefore thought of interest to thoroughly and systematically study the L-emission spectrum of neodymium with a view to searching for the presence and measuring the wavelengths of hitherto unobserved transitions. Consequently, in this paper, we report for the first time the existence of the $\mathrm{L}_{2} \mathrm{O}_{2,3}$ and $\mathrm{L}_{3} \mathrm{O}_{2,3}$ transitions at $\lambda=1846.1$ and 2000.6 X.U., respectively.

The experimental setup employed for the study was similar to one described elsewhere [2]. All of our microphotometer records show two new lines in L-emission spectrum of neodymium. One of the lines is found bracketed between $\mathrm{L} \gamma_{8}{ }^{\prime}\left(\mathrm{L}_{2} \mathrm{~N}_{6,7}\right)$ and $\mathrm{L} \gamma_{8}\left(\mathrm{~L}_{2} \mathrm{O}_{1}\right)$ lines while the other one is found between the $\mathrm{L} \beta_{7}{ }^{\prime}\left(\mathrm{L}_{3} \mathrm{~N}_{6,7}\right)$ and $\mathrm{L} \beta_{7}\left(\mathrm{~L}_{3} \mathrm{O}_{1}\right)$ lines. These lines clearly appear separated on the microphotometer records. The records are exactly similar to the one reproduced in our paper on europium-63 [4]. The wavelengths of these lines were found to be 1846.1 and 2000.6 X.U. by taking $\mathrm{NdL} \gamma_{3}(\lambda=1792.7 \mathrm{X} . \mathrm{U}$.$) ,$ $\operatorname{NdL} \gamma_{1}(\lambda=1874.0$ X.U. $), \quad \operatorname{NdL} \gamma_{5}(\lambda=$ 1931.5X.U.), and $\operatorname{NdL} \beta_{2,15}(\lambda=$ 2031.8 X.U.) as the reference lines. These two new lines have been assigned by us to $\quad \mathrm{L}_{2} \mathrm{O}_{2,3}\left(5 \mathrm{~d}_{5 / 2,3 / 2} \rightarrow 2 \mathrm{p}_{1 / 2}\right)$ and $\mathrm{L}_{3} \mathrm{O}_{2,3}\left(5 \mathrm{~d}_{5 / 2,3 / 2} \rightarrow 2 \mathrm{p}_{3 / 2}\right)$ transitions, respectively. As seen from Table 1, the observed values of $v / R$ for these new lines are in good agreement with those calculated from energy levels [3]. Also the corresponding $(v / R)^{1 / 2}$ values have been found to fit nicely in the Moseley plots (not reproduced here).
Reference to the wavelength tables [5] shows that the only chances of misinterpretation of the newly measured line at $\lambda=$ 1846.1 X.U. are due to second-order reflections of ${ }^{77} \mathrm{Ir} \mathrm{L}_{1} \mathrm{O}_{4,5}(2 \lambda=1844.8$ X.U.), ${ }^{80} \mathrm{HgL} \gamma_{5}(2 \lambda=1845.22$ X.U. $)$,

${ }^{35} \mathrm{BrK} \beta_{5}(2 \lambda=1847.2$ X.U. $)$,

${ }^{37} \mathrm{RbK} \alpha_{1}(2 \lambda=1847.26$ X.U. $)$,

and

${ }^{83} \mathrm{BiL} \beta_{5}(2 \lambda=1847.28$ X.U.). Similarly, the only possibility of wrong assignment of the second line at $\lambda=2000.6$ X.U. is that it may be second-order reflection of ${ }^{76} \mathrm{OsL} \gamma_{6}(2 \lambda=1998.0$ X.U. $)$ or ${ }^{82} \mathrm{PbL}_{3} \mathrm{~N}_{3}$ $(2 \lambda=1996.8$ X.U.), other possibilities being ruled out on account of experimental conditions. These interferences have also been completely ruled out before assigning transitions to newly observed lines. Hence the existence of $\mathrm{L}_{2} \mathrm{O}_{2,3}$ and $\mathrm{L}_{3} \mathrm{O}_{2,3}$ transitions in the L-emission spectrum of neodymium has been conclusively established.

We would like to comment here on the question of whether the numerous states concomitant with the three $4 \mathrm{f}$ electrons produce a detectable splitting in neodymium [6]. In this context we observe that in the L-emission spectrum of neodymium, the transitions from $L_{2}\left(2 p_{1 / 2}\right)$ to $4 f_{5 / 2}$ and $4 \mathrm{f}_{7 / 2}$ states appear as a single line, i.e., $\mathrm{L} \gamma_{8}{ }^{\prime}$. The states $4 \mathrm{f}_{5 / 2}$ and $4 \mathrm{f}_{7 / 2}$ are not found separated with the experimental setup employed by us. Similar is the case with the transition from $L_{3}\left(2 p_{3 / 2}\right)$ to $4 f_{5 / 2}$ and $4 f_{7 / 2}$. It may be pointed out here that our spectrometer gives a dispersion of 12 X.U./mm and can resolve $\operatorname{Mo} K \beta_{1,3}$ lines $(\Delta \lambda=0.572 \mathrm{X}$.U. $)$ clearly. The transitions from $L_{1}\left(2 s_{1 / 2}\right)$ to $4 f_{5 / 2}$ and $4 f_{7 / 2}$ states also appear as a single line (c.g., see microphotometer record given in our paper on lanthanum [7]). Thus the numerous states concomitant with the few $4 \mathrm{f}$ electrons do

Table 1. Data for the newly observed lines in neodymium

\begin{tabular}{|c|c|c|c|c|c|}
\hline \multirow[t]{2}{*}{ Transition } & \multirow[t]{2}{*}{ Nature } & \multicolumn{2}{|l|}{$\lambda$} & \multicolumn{2}{|c|}{$v / R^{\mathrm{a}}$ Values } \\
\hline & & [X.U.] & {$[\mathrm{m} \AA]^{\mathrm{a}}$} & $\begin{array}{l}\text { with } \\
\text { observed } \\
\lambda[\mathrm{m} \AA]\end{array}$ & $\begin{array}{l}\text { calculated } \\
\text { [3] }\end{array}$ \\
\hline $\mathrm{L}_{2} \mathrm{O}_{2,3}$ & Forbidden & 1846.1 & 1849.9 & 492.603 & 492.485 \\
\hline $\mathrm{L}_{3} \mathrm{O}_{2,3}$ & Quadrupole & 2000.6 & 2004.7 & 454.565 & 454.737 \\
\hline
\end{tabular}


not produce detectable splitting in the Lemission spectra of the light rare-earth elements.

Received October 4, 1977 and April 18, 1978

1. Friman, E. : Phil. Mag. 32, 497 (1916); Hjalmar, E.: Z. Phys. 7, 341 (1921); Coster, D.: Phil. Mag. 44, 546 (1922); Dauvillier, A.: Compt. Rend. 176, 1381 (1923); Richtmyer, R.D.: Phys. Rev. 38, 1802 (1931); Gokhale, B.G., Shukla, S.N.: J. Phys. B 3, 1175 (1970)

2. Shrivastava, B.D., Jain, R.K., Dubey, V.S.: Can. J. Phys. 55, 1521 (1977)
3. Bearden, J.A., Burr, A.F.: Atomic Energy Levels. Oak Ridge: U.S. Atomic Energy Commission 1965

4. Shrivastava, B.D., Jain, R.K., Dubey, V.S.: J. Phys. B 8, 2948 (1975)

5. Cauchois, Y., Hulubei, H.: Tables de constantes et donnèes numeriques I-longueurs d'onde des emissions $X$ et des discontinuités d'absorption X. Paris: Herman 1947; Bearden, J.A.: X-ray Wavelengths. Oak Ridge: U.S. Atomic Energy Commission 1964

6. Spector, N., Bonnelle, C., Dufour, G. Chem. Phys. Lett. 41, 199 (1976)

7. Shrivastava, B.D., Jain, R.K., Dubey, V.S.: Phys. Lett. A 59, 323 (1976)

\section{Rabbit $\beta$-Globin mRNA Sequences Bounding a Noncoding Insert Are Self-complementary}

\author{
M. Philipp and D. Ballinger \\ Department of Chemistry, City University of New York, \\ Herbert H. Lehman College, Bronx, New York 10468
}

\section{H. Seliger \\ Universität Ulm, Sektion Polymere, D-7900 Ulm}

Recent studies have shown that the DNA sequences which code for some eukaryotic mRNA's are separated by large interior spacer regions [1-3]. In the DNA coding for rabbit $\beta$-hemoglobin, a spacer region of 600 bases has been found to exist, separating the $\beta$-globin-coding region near the point coding for amino acid number 110 [1]. In the DNA coding for mouse $\beta$-hemoglobin chains, evidence has been found for a similar spacer region situated near the point coding for amino acid number 104 [3].

It is apparent that some mechanism must exist to prevent interior nucleotide spacers from appearing in the final messenger RNA.

We have been studying the interrelationship of amino acid sequence and mRNA hairpin-loop structure [4]. For this purpose, we have prepared several computer programs which aid in identification of RNA hairpin-loop structures and in evaluation of their thermodynamic stability [5]. One of these programs is capable of accepting RNA and DNA sequence data. When the sequence data derived from rabbit $\beta$-globin chain cDNA [6] and human $\beta$-globin chain cDNA [7] were published, we applied this program to these data: This application was prompted in part by thermal hypochromicity data showing that eukaryotic mRNA may have considerable secondary structure [8]. Analysis of the program outputs showed that many stable hairpin-loop structures are possible for rabbit $\beta$-globin mRNA and human $\beta$-globin mRNA. Analysis of the human $\beta$-globin mRNA data has shown the existence of eight hairpin loops, each of which, in isolation, is thermodynamically stable with $\Delta G$ values less than $-50 \mathrm{kcal} / \mathrm{mol}$. The single most stable hairpin loop found using the human mRNA data includes 91 base pairs and has an estimated $\Delta G$ value of $-92 \mathrm{kcal} / \mathrm{mol}$.

Additional analyses have been carried out on the rabbit $\beta$-globin mRNA sequence data. In particular, we searched for very stable hairpin loops involving nucleotide positions 360-390, which correspond to amino acid positions 102-111. Two mutually exclusive hairpin loops were found which possess $\Delta G$ values less than $-50 \mathrm{kcal} / \mathrm{mol}$. Both extend from nucleotide number 234 to nucleotide number 485 . One contains 61 base pairs, and has a $\Delta G$ value of $-66 \mathrm{kcal} / \mathrm{mol}$. The other hairpin loop (Fig. 1) contains 68 base pairs and has an estimated $\Delta G$ value of $-94 \mathrm{kcal} / \mathrm{mol}$. Since both loops involve nucleotide positions in the region where an internal spacer exists in the DNA-gene sequence, the effect of a 600-base insertion on the thermodynamic stability of these hairpin loops was estimated. It was found that the stability of the hairpin loop shown in Figure 1, when in an RNA molecule containing the spacer region, is $-83 \mathrm{kcal} / \mathrm{mol}$, only slightly different from the stability in the absence of the spacer. The estimated stability of the

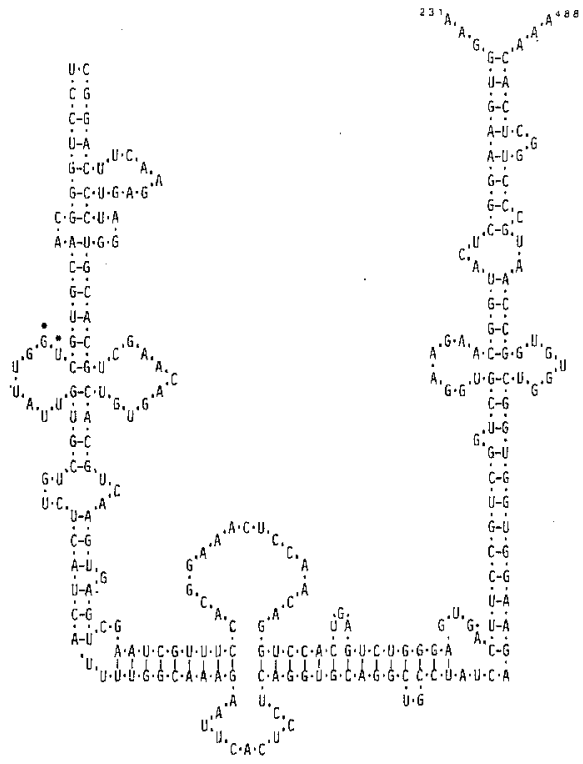

Fig. 1. A hairpin-loop structure bounding the nucleotides coding for leucine-110 in rabbit $\beta$-globin mRNA. The sequence shown extends from mRNA nucleotide number 231 to nucleotide number 488 . The second and third nucleotides coding for leucine-110, the position of a 600-base insert in the appropriate gene, are indicated by *. Dots represent internucleotide phosphodiester bonds, dashes indicate basepairing

hairpin loop not shown, when containing a 600 -base spacer, is $-55 \mathrm{kcal} / \mathrm{mol}$.

It is therefore to be expected that, if the internal spacer sequence that exists in the rabbit $\beta$-globin gene is transcribed into mRNA, this spacer must be involved in hairpin-loop formation, perhaps of the type illustrated in Figure 1. It must be noted that, while it is possible that another, as yet undetected type of secondary structure may have sufficient stability to prevent the loop from being a significant aspect of the rabbit mRNA structure, any other, more stable structure must have enough net stability to cause the association of the mRNA segments separated by the spacer region.

This suggests a model for posttranscriptional removal of the spacer region. This model depends on the transcription of both coding and noncoding regions into RNA, the excision of large, internal spacers bounded by hairpin loops, and ligation of the resulting two RNA fragments which are held in physical proximity by the selfcomplementary regions which form the hairpin loops in the intact molecule.

Excision might be done by a sequence and conformation-dependent RNase [9]. Ligation might be done by an RNA ligase, 